\title{
Electrode and Redox Potentials of Molybdenum and Stability of Molybdenum Chloro-Species in Alkali Chloride Melts
}

\author{
V. A. Volkovich, ${ }^{\mathrm{a}, *, \mathrm{z}}$ A. B. Ivanov, ${ }^{\mathrm{a}}$ R. V. Kamalov, ${ }^{\mathrm{a}}$ D. S. Maltsev, ${ }^{\mathrm{a}}$ B. D. Vasin, ${ }^{\mathrm{a}}$ \\ and T. R. Griffiths ${ }^{\mathrm{b}}$ \\ ${ }^{a}$ Department of Rare Metals and Nanomaterials, Institute of Physics and Technology, Ural Federal University, \\ Ekaterinburg 620002, Russia \\ ${ }^{b}$ Energy Process Developments Ltd., London, SE1 4AG, United Kingdom
}

\begin{abstract}
Molybdenum electrode and Mo(III)/(IV) redox potentials were measured in fused alkali chlorides. Experiments were performed in individual salts $(\mathrm{LiCl}, \mathrm{NaCl}, \mathrm{KCl}, \mathrm{RbCl}$ and $\mathrm{CsCl}$ ) and in several binary and ternary eutectic or low-melting mixtures between 633 and $1173 \mathrm{~K}$ (depending on the melting point of the solvent salt). Formal standard electrode potentials $E^{*} \mathrm{Mo} / \mathrm{Mo}$ (III) and redox potentials $E^{*} \mathrm{Mo(III)/Mo(IV)} \mathrm{in} \mathrm{respect} \mathrm{to} \mathrm{Cl}^{-} / \mathrm{Cl}_{2}$ couple and Gibbs free energy change of formation of molybdenum(III) chloride in alkali chloride melts were calculated. Electronic absorption spectra of $\mathrm{Mo}(\mathrm{III})$ ions were recorded, and spectroscopic parameters of $\mathrm{MoCl}_{6}{ }^{3-}$ complex ions determined. High temperature spectroscopy measurements were used to study the stability of Mo(III) chloro-species in fused chlorides and the reaction rates of Mo(III) ions disproportionation were also determined. Diffusion coefficients of molybdenum ions in $\mathrm{LiCl}-\mathrm{KCl}-\mathrm{CsCl}$ and $\mathrm{NaCl}-\mathrm{CsCl}$ eutectic based melts were determined from the results of electrochemical measurements. (C) The Author(s) 2017. Published by ECS. This is an open access article distributed under the terms of the Creative Commons Attribution 4.0 License (CC BY, http://creativecommons.org/licenses/by/4.0/), which permits unrestricted reuse of the work in any medium, provided the original work is properly cited. [DOI: 10.1149/2.0511708jes] All rights reserved.

(cc) BY
\end{abstract}

Manuscript submitted February 6, 2017; revised manuscript received July 7, 2017. Published July 20, 2017. This was Paper 3499 presented at the Honolulu, Hawaii, Meeting of the Society, October 2-7, 2016. This paper is part of the JES Focus Issue on Progress in Molten Salts and Ionic Liquids.

Molybdenum has many properties (including high melting point, corrosion resistance, and good strength at elevated temperatures, low thermal neutron capture cross-section, good thermal conductivity and a relatively low thermal expansion coefficient) that make it attractive for various industrial applications. Molybdenum is also of great interest for the nuclear energy field as a construction and a nuclear fuel component material. Of all types of uranium nuclear fuels, metallic uranium obviously offers the highest concentration of the fissile material. Depending on temperature, pure solid uranium can exist in one of three phases $(\alpha, \beta$ or $\gamma)$ and the temperature of $\beta \rightarrow \gamma$ transformation is $1049 \mathrm{~K}$. The high temperature $\gamma$-U phase exhibits the best performance under irradiation. ${ }^{1,2}$ To stabilize this phase at room temperature a number of alloying elements can be employed (e.g., Nb, $\mathrm{Zr}$, Mo, etc.), of which molybdenum attracted the most attention on the basis of its cost and the required concentration in the alloy. ${ }^{2-4}$

Molten salts can be employed in a number of technological processes involving molybdenum. Alkali chloride based melts can serve as electrolytes for molybdenum electrowinning and electrorefining, as well as for producing molybdenum coatings on other metals. Pyrochemical reprocessing of spent nuclear fuels (SNFs) is another field where molten salts can be employed, and this is a feasible option for treating irradiated U-Mo based metallic fuels. Non-aqueous hightemperature pyrochemical reprocessing can also be used for other types SNFs, where molybdenum has accumulated as a fission product. In metallic SNFs molybdenum is present in the elemental form, whereas in the oxide fuels this element forms molybdate(VI) species, $\mathrm{Mo}(\mathrm{IV})$ oxide (with very limited solubility in the $\mathrm{UO}_{2}$ matrix) and molybdenum metal (alloyed with $\mathrm{Tc}, \mathrm{Ru}, \mathrm{Rh}$ and $\mathrm{Pd}$ ) ${ }^{5-7}$ Designing a molten salt electrochemical process relies on information concerning molybdenum speciation, properties and its behavior in the electrolyte.

Some aspects of molybdenum chemistry in fused chlorides were considered earlier, ${ }^{8}$ primarily in relation to pyrochemical reprocessing, but these did not include electrochemical processes. Electrochemistry of molybdenum in chloride melts first attracted attention several decades ago but no systematic study of the electrode potentials has been performed, with the exception of the earlier studies by Ryzhik and Smirnov. ${ }^{9-16}$ They determined molybdenum standard electrode potentials in melts based on individual alkali chlorides $(\mathrm{LiCl}, \mathrm{KCl}$, $\mathrm{CsCl}$ ) and in the $\mathrm{LiCl}-\mathrm{KCl}$ eutectic mixture. Their results, however, did not agree with the data by Senderoff and Brenner ${ }^{17}$ and Selis, ${ }^{18}$ who reported significantly more positive potential values for $\mathrm{LiCl}-\mathrm{KCl}$ based melts at 873-1173 K and 733-813 K, respectively. Subsequent measurements in $\mathrm{NaCl}-\mathrm{KCl}$ equimolar mixture at $992-1088 \mathrm{~K}^{19,20}$ and $\mathrm{NaCl}-\mathrm{CsCl}$ eutectic at $845-1010 \mathrm{~K}^{21}$ also resulted in more positive molybdenum electrode potential values than could have been expected from the data of Ryzhik and Smirnov. Thus, there was noticeable disagreement between the data reported over the past years. Very little attention was subsequently paid to measuring molybdenum electrode potentials in fused chlorides.

Molybdenum is a polyvalent metal and it is generally agreed now that the lowest oxidation state of molybdenum in high temperature chloride melts is $+3 .{ }^{17-21}$ Such observation corresponds to the trend of increasing the lowest stable oxidation state of transition $d$-block metal ions in chloride melts upon increasing the period number, i.e. from $3 d$ to $4 d$ and $5 d$. For instance, the lowest oxidation state of chromium in chloride melts is $+2^{22}$ and that of tungsten is $+4{ }^{23,24}$ Co-deposition of lower oxidation state molybdenum species together with the metal on a cathode was observed during electrolysis at low temperatures (in NaCl-KCl-CsCl and $\mathrm{NaCl}-\mathrm{KCl}-\mathrm{MgCl}_{2}$ based melts) at high molybdenum concentrations. ${ }^{25}$ This compound was not characterised and was said to be insoluble in the melt. Earlier reports also mentioned a possibility that polynuclear molybdenum(III) ions can exist in the melts ${ }^{26-28}$ but subsequent spectroscopy studies produced no evidence of such species. Higher oxidation states of molybdenum in fused chlorides have yet to be sufficiently studied. Molybdenum(IV) and $(\mathrm{V})$ chloro-species could be formed under certain conditions and were characterised primarily by spectroscopy. ${ }^{29-31}$ Molybdenum(VI) species can be present in chloride melts only in the form of oxygen containing ions.

The present study was aimed at studying molybdenum electrochemical properties and speciation in alkali chloride based melts, focusing on molybdenum electrode potentials and probing the $\mathrm{Mo}(\mathrm{III}) / \mathrm{Mo}(\mathrm{IV})$ oxidation-reduction process.

\section{Experimental}

*Electrochemical Society Member

${ }^{\mathrm{z} E}$ E-mail: v.a.volkovich@urfu.ru
To assess the effect of the melt cationic composition on molybdenum speciation and behavior, the experiments were performed in 
individual alkali chlorides ( $\mathrm{LiCl}, \mathrm{NaCl}, \mathrm{KCl}, \mathrm{RbCl}, \mathrm{CsCl}$ ), as well as in several binary and ternary mixtures of eutectic or low melting compositions. These included $\mathrm{LiCl}-\mathrm{KCl}(58 \mathrm{~mol} \% \mathrm{KCl}$, m.p. $625 \mathrm{~K}) ; \mathrm{NaCl}-\mathrm{KCl}(50 \mathrm{~mol} \% \mathrm{NaCl}$, m.p. $923 \mathrm{~K})$; NaCl-CsCl (34 mol.\% NaCl, m.p. $763 \mathrm{~K}), \mathrm{KCl}-\mathrm{CsCl}(36 \mathrm{~mol} \% \mathrm{KCl}$, m.p. $879 \mathrm{~K})$; $\mathrm{LiCl}-\mathrm{KCl}-\mathrm{CsCl}(57.5 \mathrm{~mol} \% \mathrm{LiCl}, 16.5 \mathrm{~mol} \% \mathrm{KCl}, \mathrm{m} . \mathrm{p} .536 \mathrm{~K})$ and $\mathrm{NaCl}-\mathrm{KCl}-\mathrm{CsCl}(30 \mathrm{~mol} . \% \mathrm{NaCl}, 24.5 \mathrm{~mol} . \% \mathrm{KCl}$, m.p. $753 \mathrm{~K})$ mixtures. Commercially available alkali chlorides were used and these included $\mathrm{LiCl}(99+\%$, Aldrich), $\mathrm{NaCl}(99.9+\%$, Reakhim), $\mathrm{KCl}$ $(99.8+\%$, Reakhim) and $\mathrm{CsCl}(99.9+\%$, Reakhim). Salts were dried under vacuum at $573 \mathrm{~K}$ for 3 hours in silica cells. The temperature was then increased to ca. 50 degrees above the melting point of the salt. The cell was filled with argon (99.998\%) and the molten salt was sparged with gaseous hydrogen chloride or a mixture of chlorine and hydrogen chloride for several hours and then held under vacuum to remove the gases dissolved. Mixtures of alkali chlorides were prepared by fusing together the individual salts thus prepared. All salt mixtures were stored in an argon filled dry box prior to use.

Molybdenum-containing melts were produced either by anodic dissolution of the metal or by dissolving potassium hexachloromolybdate(III). The latter compound was prepared using the procedure given by Senderoff and Brenner; ${ }^{32}$ starting potassium molybdate was synthesized by reacting stoichiometric amounts of molybdenum trioxide $(99.5+\%$, Reakhim) and potassium carbonate $(99+\%$, Reakhim). The impurities content in the compound prepared was not determined. Molybdenum metal (99.95\%, wire and foil) was obtained from Alfa Aesar. Anodic dissolution of molybdenum is a three-electron process. ${ }^{33,34}$ Previous high temperature spectroscopy studies showed that six-coordinated $\mathrm{MoCl}_{6}{ }^{3-}$ ions were formed in the melt irrespectively of the method used for introducing molybdenum ions (anodic dissolution of the metal or dissolution of $\left.\mathrm{K}_{3} \mathrm{MoCl}_{6}\right)$. ${ }^{31,35}$ The concentration of molybdenum in the quenched melt samples was determined photometrically with thiocyanate. ${ }^{36}$ Volumetric analysis (oxidimetric titration) was employed to estimate the mean oxidation state of molybdenum in the quenched melts. ${ }^{37} \mathrm{~A}$ sample of the melt was dissolved in a known volume of ammonium vanadate solution $(0.01 \mathrm{M}$ in $5 \mathrm{M}$ sulfuric acid) resulting in oxidation of all molybdenum to the oxidation state +6 . The excess vanadate was then determined by titrating with Mohr salt solution $(0.01 \mathrm{M}$ of ammonium iron sulfate in $5 \mathrm{M}$ $\mathrm{H}_{2} \mathrm{SO}_{4}$ ) in the presence of phenylanthranilic acid as redox indicator. The mean oxidation state of molybdenum $\left(n_{o x}\right)$ was calculated using the following equation:

$$
n_{o x}=6-\left(C_{\mathrm{V}} \cdot V_{\mathrm{V}}-C_{\mathrm{Fe}} \cdot V_{\mathrm{Fe}}\right) \cdot 95.94 /\left(m \cdot \omega_{\mathrm{Mo}}\right),
$$

where $C_{\mathrm{V}}$ and $C_{\mathrm{Fe}}$ are the concentrations of ammonium vanadate and Mohr salt solutions, respectively, $\mathrm{M} ; V_{\mathrm{V}}$ and $V_{\mathrm{Fe}}$ are the volumes of ammonium vanadate and Mohr salt solutions used, $\mathrm{dm}^{3} ; m$ is the melt sample weight used for the analysis, $g$; and $\omega_{\mathrm{Mo}}$ is molybdenum concentration in the melt, mass fraction.

High temperature spectroscopy measurements.-Electronic absorption spectra of molybdenum-containing melts were recorded between 350 and $1100 \mathrm{~nm}$ using a custom-built set-up based on a double channel spectrometer AvaSpec-2048FT-2-SPU (Avantes) and an optical furnace TF1726 (Instron SFL). The melts were held in standard $1 \mathrm{~cm}$ path length silica optical cells equipped with the necessary arrangements and electrodes, i.e., for performing molybdenum metal anodic dissolution, sampling the melt, etc. The electrodes were positioned in the cell that spectra could be recorded in the course of the metal anodic dissolution without interrupting the process.

Electrochemistry measurements.-Electrode potentials of molybdenum were determined using the electromotive force (emf) measurements method. ${ }^{10,38}$ Measurements were performed at zero current using an Autolab PGSTAT 302N potentiostat/galvanostat. Molybdenum plate (ca. $4 \mathrm{~cm}^{2}$ ) attached to a molybdenum rod served as a working electrode. Chlorine $\left(\mathrm{Cl}^{-} / \mathrm{Cl}_{2}\right)$ or silver chloride $(\mathrm{Ag} / \mathrm{AgCl})$ electrodes were used as references, and all the measured potentials were recalculated to $\mathrm{Cl}^{-} / \mathrm{Cl}_{2}$ couple. The chlorine reference electrode was used in a number of experiments for verification of the values obtained with the silver chloride electrode. The chlorine electrode ${ }^{10}$ consisted of a silica sheath of ca $15 \mathrm{~mm}$ i.d. having an asbestos diaphragm (ca. $2 \mathrm{~mm}$ i.d.) in the bottom and containing the corresponding alkali chloride solvent melt. A graphite tube was dipped into the melt and a constant flow of gaseous chlorine was passed through this tube. The melt was thus kept saturated with chlorine and the pressure of $\mathrm{Cl}_{2}$ above the melt was equal to the ambient. The silver chloride reference electrode consisted of a silver wire dipped into a 1 mol.\% solution of $\mathrm{AgCl}$ in the $\mathrm{NaCl}-\mathrm{CsCl}$ eutectic. The electrode potential of silver in this melt is described by the following equation $(T$ in $\mathrm{K}):{ }^{39}$

$$
E^{*}{ }_{\mathrm{Ag}(\mathrm{I}) / \mathrm{Ag}}=-1.223+3.2610-4 T( \pm 0.008) \mathrm{V}
$$

Temperature was monitored using a K-type thermocouple in a beryllium oxide sheath and a silica capillary sampling tube was used for withdrawing a portion of the molten salt for further chemical analysis. Silica was used for the sheaths of the reference and counter electrodes and the bottom parts of the sheaths were closed with asbestos diaphragms. Asbestos was preliminary calcined at $973 \mathrm{~K}$ and the diaphragms were impregnated with the corresponding solvent salt prior to use. The melt was held in a glassy carbon crucible positioned in a silica cell, closed with a stopper containing all the necessary electrodes and attachments.

Formal standard electrode potentials of molybdenum were calculated from the experimentally measured potential values and molybdenum concentration determined by chemical analysis.

To determine molybdenum redox potentials, the potentiometric measurements were performed in the melts containing the products of reaction of molybdenum dioxide (or mixtures of molybdenum and molybdenum dioxide) with hydrogen chloride. In this case glassy carbon rods were used as working electrodes and with silver chloride electrode as the reference.

Cyclic voltammetry and chronopotentiometry measurements were also performed employing the Autolab PGSTAT $302 \mathrm{~N}$ potentiostat. A silver chloride electrode was used here as the reference and a glassy carbon rod ( $2.48 \mathrm{~mm}$ dia.) sheathed from the sides by a beryllium oxide tube acted as a working electrode. The surface area of the working electrode was $0.048 \mathrm{~cm}^{2}$. A silica tube closed with a diaphragm and contained a molybdenum wire dipped into a $\mathrm{MCl}-\mathrm{PbCl}_{2}$ melt $(\mathrm{M}=$ alkali metal) served as a counter electrode. The surface area of the counter electrode was ca. $1.2 \mathrm{~cm}^{2}$. The design of the counter electrode allowed separating any counter electrode reaction from the bulk of the electrolyte.

\section{Results and Discussion}

Stability of Mo(III) ions in chloride melts.-Electronic absorption spectroscopy offers a convenient tool for monitoring processes involving Mo(III) species in fused salts. Molybdenum(III) containing chloride melts have characteristic electronic absorption spectra (EAS) in the visible region. The EAS contain two relatively intense absorption bands with clearly defined maxima around 580 and $440 \mathrm{~nm}$ and a weak shoulder around $680 \mathrm{~nm}$, Fig. 1. The absorption bands originate from the electronic transitions in the six-coordinated $\mathrm{MoCl}_{6}{ }^{3-}$ complex ions, i.e. two spin-allowed transitions $\left({ }^{4} A_{2 \mathrm{~g}} \rightarrow{ }^{4} T_{1 \mathrm{~g}}\right.$ and ${ }^{4} A_{2 \mathrm{~g}} \rightarrow{ }^{4} T_{2 \mathrm{~g}}$ ) and a spin forbidden transition ${ }^{4} A_{2 \mathrm{~g}} \rightarrow{ }^{2} T_{2 \mathrm{~g}}$. Spectra recorded in the course of molybdenum anodic dissolution showed a steady absorbance increase. The concentration of molybdenum(III) ions (calculated using Beer's law and results of the chemical analysis of the final melt) linearly increased with time, Fig. 2

The results of analysis of Mo(III) EAS in various chloride melts are summarized in Table I. Positions of the absorption bands were determined after resolving the spectra into constituent Gaussian bands except for the spectra taken from the literature where the peak positions reported by the authors or estimated from spectral curve profiles were used. Absorption bands shifted toward lower energy (higher wavelengths) upon increasing temperature or mean radius of the alkali metal cation. Ligand field splitting energy $D q$ also decreases with 


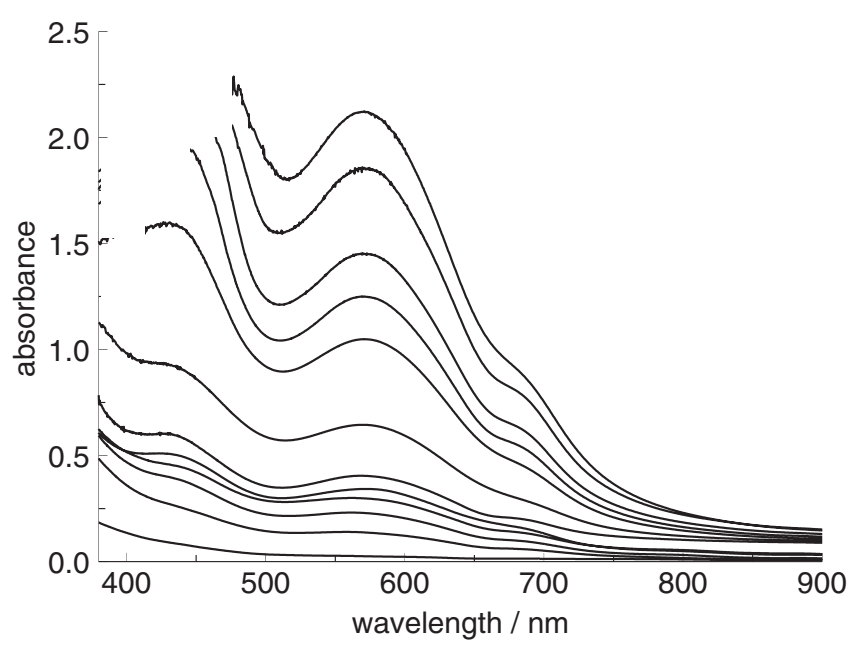

Figure 1. EAS recorded during anodic dissolution of molybdenum in $\mathrm{NaCl}-$ $\mathrm{CsCl}$ melt at anodic current density of $0.006 \mathrm{~A} / \mathrm{cm}^{2}, 823 \mathrm{~K}$. Time after commencing dissolution (bottom to top, $\min$ ): $2 ; 2.5 ; 4 ; 5.5 ; 7.5 ; 17.5 ; 20 ; 25.5$; $31 ; 36 ; 41$ and 46 .

temperature and cationic radius. Racah parameter $B$ increases with the radius of the cation resulting in increasing the nephelauxetic parameter $\beta$ characterizing the degree of "ionicity" of bonds in the complex ions. The value of $\beta$ varies from ca. 0.7 to ca. 0.9 upon changing the melt cation from $\mathrm{Li}^{+}$to $\mathrm{Cs}^{+}$. Racah parameter $C$ was determined from

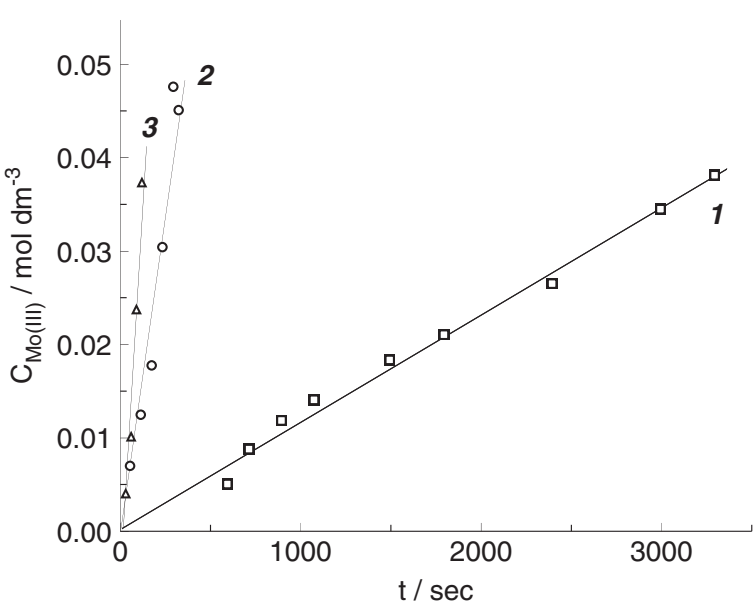

Figure 2. Changing $\mathrm{Mo}(\mathrm{III})$ concentration in $\mathrm{NaCl}-\mathrm{CsCl}$ based melts during anodic dissolution of molybdenum from the results of EAS measurements, 923 K. Anodic current, A: 0.01 (1), 0.1 (2) and 0.275 (3).

the energy of the low intensity spin-forbidden transition ${ }^{4} A_{2 \mathrm{~g}} \rightarrow{ }^{2} T_{2 \mathrm{~g}}$ and the values obtained should be treated as approximate. No clear effect of temperature and melt composition on the value of this parameter was found. Ligand field stabilization energy $\delta$ of $\mathrm{MoCl}_{6}{ }^{3-}$ ion decreases from $\mathrm{LiCl}$ to $\mathrm{CsCl}$ based melts indicating increasing stability of the complex ion due to lowering polarizing effect of the outer sphere cations.

Table I. Spectroscopic parameters of Mo(III) species in chloride melts.

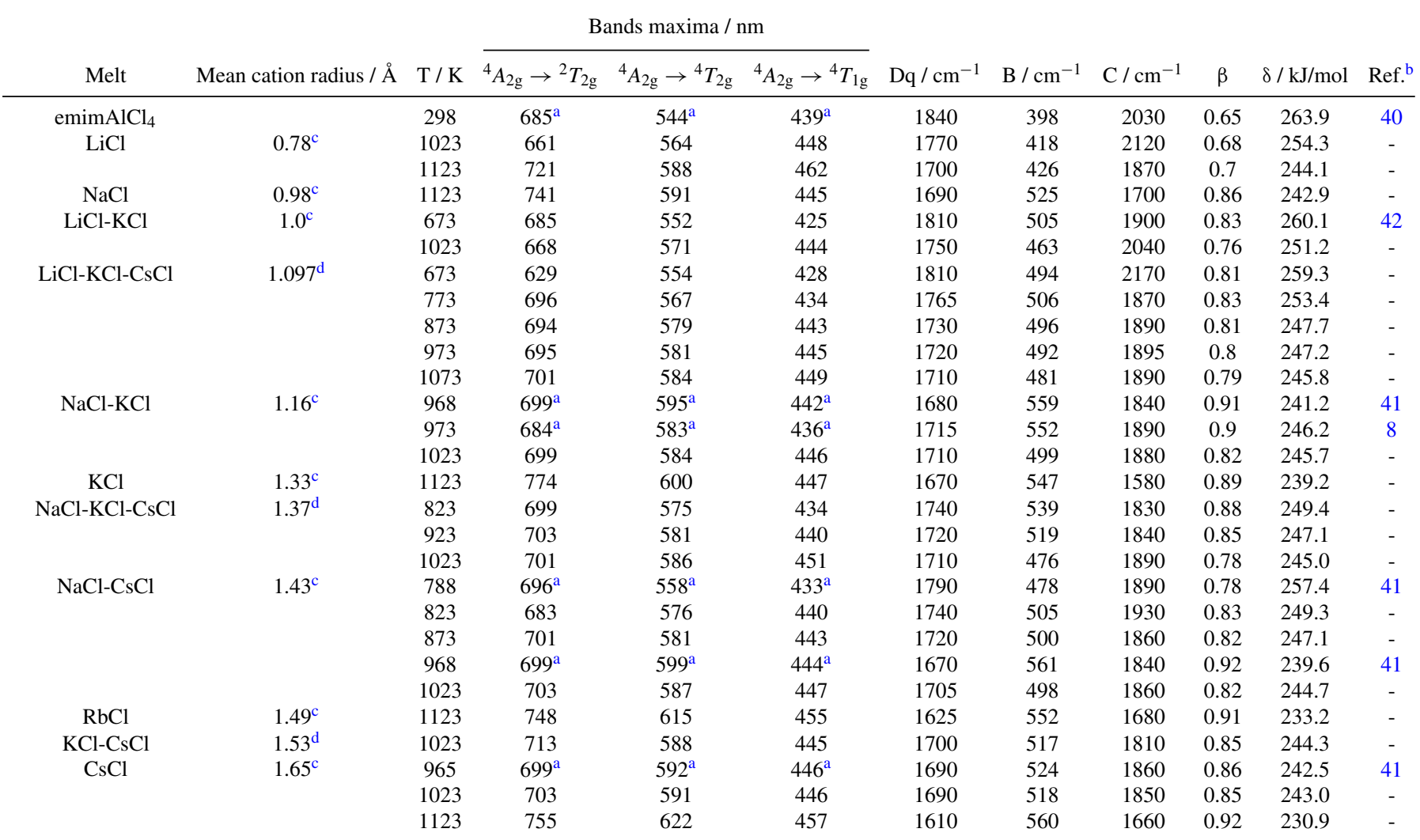

${ }^{a}$ Estimated without resolving the spectra into individual bands.

${ }^{\mathrm{b}}$ The dash in the reference column indicates the results obtained in the present study.

${ }^{\mathrm{c}}$ Taken from Smirnov. ${ }^{10}$

${ }^{\mathrm{d}}$ Calculated here from the molar composition of the mixture. 


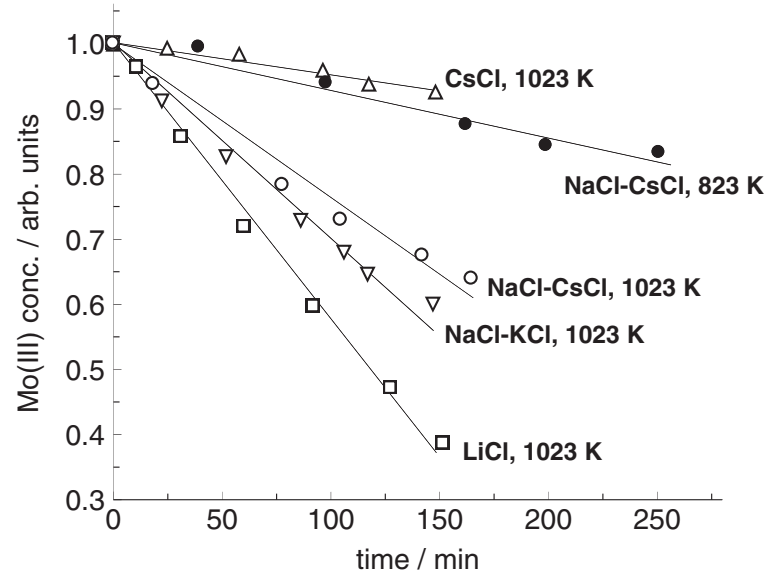

Figure 3. Decreasing Mo(III) concentration in alkali chloride based melts held under argon atmosphere. Melt composition and temperature shown for each set of data.

Molybdenum chloro-ions have limited stability in fused alkali chlorides and the concentration of molybdenum(III) ions in high temperature chloride melts left under an inert atmosphere decreased over time. Electrochemical, chemical and spectroscopy studies showed that Mo(III) chloro-species in chloride melts can undergo disproportionation: ${ }^{26,42}$

$$
5 \mathrm{MoCl}_{6}{ }^{3-} \leftrightarrow 2 \mathrm{Mo} \downarrow+3 \mathrm{MoCl}_{5} \uparrow+15 \mathrm{Cl}^{-}
$$

resulting in a gradually decreasing molybdenum concentration in the melt and precipitation of fine molybdenum metal particles. EAS measurements showed that Mo(III) concentration in the melt prepared by anodic dissolution of molybdenum metal or by dissolving $\mathrm{K}_{3} \mathrm{MoCl}_{6}$, decreased over time and this decrease was essentially linear, Fig. 3. Molybdenum concentration in the melt was determined from the absorption values using Beer's law. The rate at which Mo(III) concentration decreased depended on temperature and cationic melt composition, the higher the temperature or smaller the cation, the faster the Mo(III) concentration dropped. The reaction rates determined for various melt compositions are summarized in Table II. The starting molybdenum(III) concentration in the melt was around $0.15-0.2$ $\mathrm{mol} / \mathrm{kg}$ and the reaction rates increased with temperature or decreasing alkali cation radius, showing that the equilibrium of Reaction 3 was shifted to the right at elevated temperatures or in the presence of cations with high ionic momentum. Such instability of Mo(III) containing melts complicates potentiometric measurements and can be one of the possible reasons for discrepancy in reported molybdenum electrode potential values. ${ }^{9-21}$

Molybdenum electrode potentials in alkali chloride melts.- In the present study molybdenum powder was added to the melt during measurements to slow down the Reaction 3 and minimize its influence on the results. Potentials were taken as stationary if they did

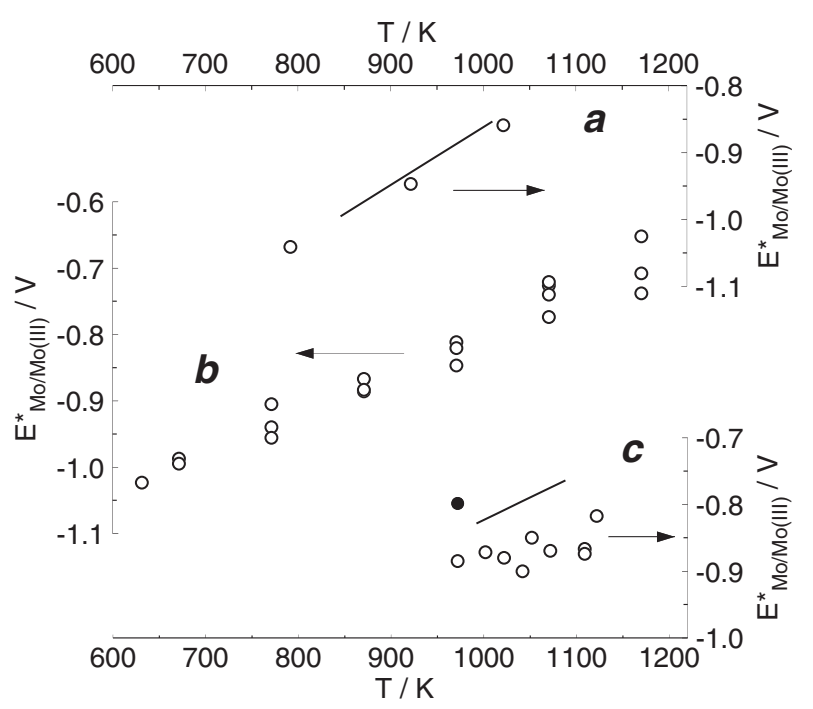

Figure 4. Molybdenum formal standard electrode potentials in $\mathrm{NaCl}-\mathrm{CsCl}$ (a), $\mathrm{LiCl}-\mathrm{KCl}-\mathrm{CsCl}$ (b) and $\mathrm{NaCl}-\mathrm{KCl}$ (c) based melts. $\mathrm{Cl}^{-} / \mathrm{Cl}_{2}$ reference couple. Empty symbols - present work; solid symbol and lines - literature data. ${ }^{19-21}$

not change by more than $5 \mathrm{mV}$ over 30 minutes. Immediately after finishing recording the potentials, a sample of the melt was withdrawn into a sampling silica capillary tube, rapidly quenched and used for the further chemical analysis. Student's $t$-distribution with $95 \%$ confidence interval was used for the statistical analysis of the experimental data.

Individual alkali metal chlorides have relatively high melting points and therefore mixtures of low-melting or eutectic compositions are preferred for technological applications. In the present study, three mixtures were selected, i.e. $\mathrm{NaCl}-\mathrm{KCl}$ (inexpensive but relatively high melting); $\mathrm{NaCl}-\mathrm{CsCl}$ (low-melting and non-hygroscopic but expensive); and $\mathrm{LiCl}-\mathrm{KCl}-\mathrm{CsCl}$ (having the lowest melting point amongst all alkali chloride mixtures). The results obtained are presented in Fig. 4 where they are also compared with the available literature data. The following equations were obtained by the linear least squares fitting and describe the temperature dependencies of the formal standard electrode potentials of molybdenum:

$$
\begin{gathered}
E_{\mathrm{Mo} / \mathrm{Mo}(\mathrm{III})}^{*}=-1.727+8.65 \cdot 10^{-4} \\
\cdot T( \pm 0.04) \mathrm{V}(\mathrm{NaCl}-\mathrm{CsCl}, 793-1023 \mathrm{~K}) \\
E^{*} \mathrm{Mo} / \mathrm{Mo}(\mathrm{III})=-1.327+4.46 \cdot 10^{-4} \\
\cdot T( \pm 0.04) \mathrm{V}(\mathrm{NaCl}-\mathrm{KCl}, 973-1123 \mathrm{~K}) \\
E^{*}{ }_{\mathrm{Mo} / \mathrm{Mo}(\mathrm{III})}=-1.405+6.05 \cdot 10^{-4} \\
\cdot T( \pm 0.04) \mathrm{V}(\mathrm{LiCl}-\mathrm{KCl}-\mathrm{CsCl}, 633-1173 \mathrm{~K})
\end{gathered}
$$

\begin{tabular}{|c|c|c|c|c|c|}
\hline \multirow[b]{2}{*}{ Melt } & \multirow[b]{2}{*}{$T / \mathrm{K}$} & \multicolumn{2}{|c|}{ Starting Mo(III) conc. } & \multicolumn{2}{|c|}{ Reaction rate } \\
\hline & & $\mathrm{mol} \mathrm{kg}^{-1}$ & $\mathrm{~mol} \mathrm{dm}^{-3}$ & $\mathrm{~mol} \mathrm{~kg}^{-1} \mathrm{~s}^{-1}$ & $\operatorname{mol~dm}{ }^{-3} \mathrm{~s}^{-1}$ \\
\hline $\mathrm{LiCl}$ & 1023 & 0.0205 & 0.0294 & $1.38 \cdot 10^{-6}$ & $1.98 \cdot 10^{-6}$ \\
\hline $\mathrm{LiCl}-\mathrm{KCl}$ & 1023 & 0.0169 & 0.0251 & $1.30 \cdot 10^{-6}$ & $1.94 \cdot 10^{-6}$ \\
\hline $\mathrm{NaCl}-\mathrm{KCl}$ & 1023 & 0.0166 & 0.0257 & $7.51 \cdot 10^{-7}$ & $1.17 \cdot 10^{-6}$ \\
\hline \multirow[t]{2}{*}{$\mathrm{NaCl}-\mathrm{KCl}-\mathrm{CsCl}$} & 923 & 0.0158 & 0.0380 & $4.49 \cdot 10^{-7}$ & $1.08 \cdot 10^{-6}$ \\
\hline & 1023 & 0.0221 & 0.0513 & $6.09 \cdot 10^{-7}$ & $1.41 \cdot 10^{-6}$ \\
\hline \multirow[t]{2}{*}{$\mathrm{NaCl}-\mathrm{CsCl}$} & 823 & 0.0156 & 0.0401 & $1.90 \cdot 10^{-7}$ & $4.88 \cdot 10^{-7}$ \\
\hline & 1023 & 0.0143 & 0.0339 & $5.12 \cdot 10^{-7}$ & $1.21 \cdot 10^{-6}$ \\
\hline $\mathrm{KCl}-\mathrm{CsCl}$ & 1023 & 0.0194 & 0.0478 & $7.76 \cdot 10^{-7}$ & $1.92 \cdot 10^{-6}$ \\
\hline $\mathrm{CsCl}$ & 1023 & 0.0134 & 0.0359 & $1.28 \cdot 10^{-7}$ & $3.43 \cdot 10^{-7}$ \\
\hline
\end{tabular}

Table II. Rate of Reaction 3 in alkali chloride based melts 


$\begin{aligned} & \text { Table III. Molybdenum formal standard electrode potentials in } \\
& \text { fused alkali metal chlorides }\left(\mathbf{C l}^{-} / \mathbf{C l}_{\mathbf{2}} \text { reference couple). }\right.\end{aligned}$
\begin{tabular}{ccc}
$E^{*} \mathrm{Mo} / \mathrm{Mo}(\mathrm{III})$ & $E^{*} \mathrm{Mo} / \mathrm{Mo}(\mathrm{III})$ \\
$\mathrm{Melt}$ & at $1123 \mathrm{~K} / \mathrm{V}$ (present work) & at $1100 \mathrm{~K} / \mathrm{V}^{9-13,15,16}$ \\
\hline $\mathrm{LiCl}$ & $-0.720 \pm 0.040$ & -0.754 \\
$\mathrm{NaCl}$ & $-0.780 \pm 0.040$ & -1.067 \\
$\mathrm{KCl}$ & $-0.810 \pm 0.020$ & \\
$\mathrm{RbCl}$ & $-0.843 \pm 0.035$ & -1.113 \\
$\mathrm{CsCl}$ & $-0.877 \pm 0.005$ &
\end{tabular}

The potential values shift in a negative direction with increasing mean radius of the alkali cation. The results obtained here for $\mathrm{NaCl}$ $\mathrm{CsCl}$ eutectic-based melt agree closely with the earlier work. ${ }^{21}$ For the $\mathrm{NaCl}-\mathrm{KCl}$ mixture, the results obtained by Aleksandrov et al. ${ }^{20}$ were around $60-70 \mathrm{mV}$ more positive than found here, while the single point reported by Baraboshkin ${ }^{19}$ at $973 \mathrm{~K}$ was even more positive.

The temperature dependencies of the Gibbs free energy change of $\mathrm{MoCl}_{3}$ formation in the melts studied were calculated from the temperature dependencies of the formal standard electrode potentials using the standard relation between the free energy and the electrochemical cell emf, ${ }^{38}$ and the following equations were derived:

$$
\begin{aligned}
& \Delta \mathrm{G}_{\mathrm{MoCl}_{3}}^{*}=-499.9+250.4 \cdot 10^{-3} \\
& \quad \cdot T( \pm 3) \mathrm{kJ} / \mathrm{mol}(\mathrm{NaCl}-\mathrm{CsCl}, 793-1023 \mathrm{~K}) \\
& \Delta \mathrm{G}_{\mathrm{MoCl}_{3}}^{*}=-384.1+129.1 \cdot 10^{-3} \\
& \quad \cdot T( \pm 4) \mathrm{kJ} / \mathrm{mol}(\mathrm{NaCl}-\mathrm{KCl}, 973-1123 \mathrm{~K}) \\
& \Delta \mathrm{G}_{\mathrm{MoCl}_{3}}^{*}=-406.7+175.2 \cdot 10^{-3} \\
& \cdot T( \pm 1) \mathrm{kJ} / \mathrm{mol}(\mathrm{LiCl}-\mathrm{KCl}-\mathrm{CsCl}, 633-1173 \mathrm{~K})
\end{aligned}
$$

Electrode potentials of metals in fused chlorides depend on the cationic composition of the melts. Alkali metal cations form second coordination sphere around the transition metal centres and have the effect on the stability of the complexes and electrochemical and thermodynamic properties of the metal species in the melts. As shown above, the stability of Mo(III) chloro-species in alkali chloride metal decreases with decreasing alkali metal cation radius (increasing ionic momentum). To study the effect of the nature of alkali cations on molybdenum electrochemical properties, the electrode potentials were measured in the melts based on individual alkali chlorides at the same temperature. The formal standard electrode potentials determined here are presented in Table III. The following equation obtained by the linear least squares fitting of the experimental data describes the dependence of molybdenum electrode potential in fused individual alkali chlorides on the cation radius at $1123 \mathrm{~K}$ :

$$
E^{*}{ }_{\text {Mo/Mo(III) }}=0.239 / r_{\text {cation }}-1.02( \pm 0.03) \mathrm{V}
$$

Increasing the cation radius shifted the potential in the negative direction in agreement with previous reports. ${ }^{9-14,16}$ However, the $E^{*}{ }_{\mathrm{Mo} / \mathrm{Mo}(\mathrm{III})}$ values obtained in the present study were more positive than those given by Smirnov and Ryzhik at a comparable temperature, Table I, with the difference exceeding in some cases $200 \mathrm{mV}$.

Analysis of the literature ${ }^{9-21}$ showed that there is some discrepancy between the results obtained by various authors. The data available for various melts are compared in Fig. 5, where $E^{*}$ Mo/Mo(III) is presented as a function of cationic radius at $1123 \mathrm{~K}$. For individual alkali chlorides the effective ionic radii were used. ${ }^{10,43}$ For binary or ternary alkali chloride mixtures, the mean cationic radius was calculated from the molar composition of the corresponding mixture. If the measurements of molybdenum electrode potentials reported in the literature were performed below $1123 \mathrm{~K}$, the potential value presented in Fig. 5 was calculated using the potential temperature dependencies reported by the authors of the corresponding investigations. With the exception of

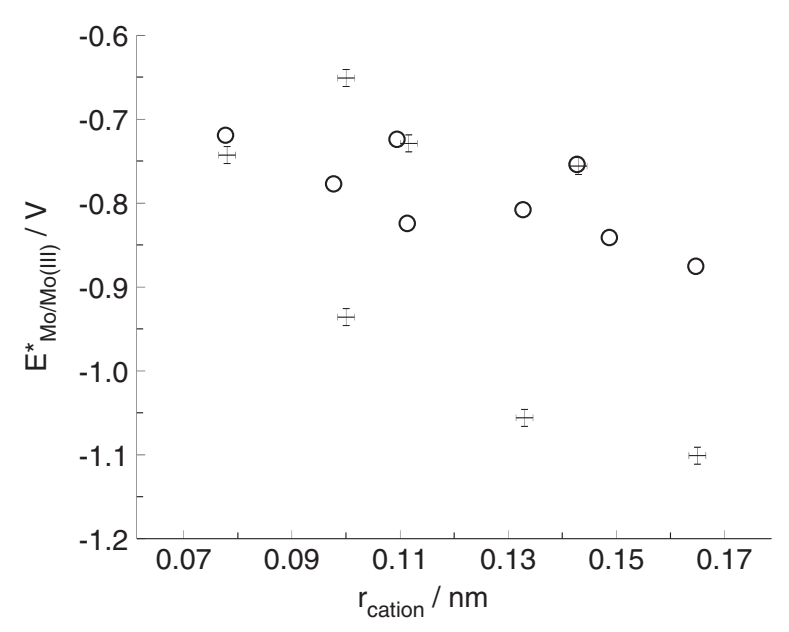

Figure 5. Formal standard electrode potentials of molybdenum (vs. $\mathrm{Cl}^{-} / \mathrm{Cl}_{2}$ couple) in fused alkali chlorides at $1123 \mathrm{~K}$. The melts are positioned according to the average cationic radii. Circles - present work; crosses - data from the literature. $^{9-21}$

those reported by Ryzhik and Smirnov for $\mathrm{CsCl}, \mathrm{KCl}$ and $\mathrm{LiCl}-\mathrm{KCl}$ based melts ${ }^{11-13,15,16}$ there is a satisfactory agreement (normally within $\pm 50 \mathrm{mV}$ ) between the data reported. Molybdenum electrode potential values obtained by Ryzhik and Smirnov were far more negative than any other available data and are likely erroneous.

Molybdenum redox potentials in alkali chloride melts.-Although molybdenum(IV) and (V) chloro-species can be formed in alkali chloride melts, very little is known about their electrochemical properties. Melts containing Mo(IV) ions can be obtained by reacting $\mathrm{MoO}_{2}$ with hydrogen chloride. ${ }^{31}$ Our previous spectroscopic and spectroelectrochemistry studies showed that Mo(IV) chloro-species are most stable at lower temperatures and in the melts containing low ionic momentum cations (cesium) ${ }^{31}$ Electronic absorption spectroscopy allowed clear distinction between Mo(III) and Mo(IV) ions. Examples of the EAS of the melts containing the products of reaction of $\mathrm{MoO}_{2}$ with $\mathrm{HCl}$ at various temperatures are presented in Fig. 6 . The spectra recorded at 823 and $873 \mathrm{~K}$ contain a well pronounced peak around $13,000 \mathrm{~cm}^{-1}$, as well as a hidden band around 16,100 $\mathrm{cm}^{-1}$ and a low energy edge of a band with the maximum above 20,000 $\mathrm{cm}^{-1}, c f$. top and middle spectra in Fig. 6. The mean oxidation state of molybdenum in these melts determined by redox titration was close to four. Analysis of the possible electronic transitions for $d^{2}$ electronic configuration showed that these bands correspond to the following transitions in the $\mathrm{MoCl}_{6}{ }^{2-}$ complex ion (in order of increasing energy): ${ }^{3} T_{1 \mathrm{~g}} \rightarrow{ }^{3} T_{2 \mathrm{~g}},{ }^{3} T_{1 \mathrm{~g}} \rightarrow{ }^{1} A_{1 \mathrm{~g}},{ }^{3} T_{1 \mathrm{~g}} \rightarrow{ }^{3} T_{1 \mathrm{~g}}(\mathrm{P})$. The second transition is spin-forbidden and therefore the intensity of the corresponding band is lower than for the spin-allowed transitions. The spectra recorded at $923 \mathrm{~K}$ contained more bands, $c f$. bottom spectrum in Fig. 6. The mean oxidation state of molybdenum in this melt determined oxidimetrically was $3.40 \pm 0.03$. The melt therefore contained a mixture of Mo(IV) and Mo(III) ions and the EAS contained a superposition of the absorption bands corresponding to the electronic transitions in $\mathrm{MoCl}_{6}{ }^{2-}\left(d^{2}\right.$-configuration $)$ and $\mathrm{MoCl}_{6}{ }^{3-}\left(d^{3}\right.$-configuration $)$ complex ions. The resolved bands corresponded to the following transitions (in order of increasing energy): ${ }^{3} T_{1 \mathrm{~g}} \rightarrow{ }^{3} T_{2 \mathrm{~g}}$ (in $\mathrm{MoCl}_{6}{ }^{2-}$ ), ${ }^{4} A_{2 \mathrm{~g}} \rightarrow{ }^{2} T_{2 \mathrm{~g}}$ (in $\mathrm{MoCl}_{6}{ }^{3-}$ ), ${ }^{4} A_{2 \mathrm{~g}} \rightarrow{ }^{4} T_{2 \mathrm{~g}}$ (in $\mathrm{MoCl}_{6}{ }^{3-}$ ), ${ }^{4} A_{2 \mathrm{~g}} \rightarrow{ }^{4} T_{1 \mathrm{~g}}$ (in $\mathrm{MoCl}_{6}{ }^{3-}$ ). The ${ }^{4} A_{2 \mathrm{~g}} \rightarrow{ }^{2} T_{2 \mathrm{~g}}$ transition is forbidden by spin and the corresponding band has low intensity. The band corresponding to the ${ }^{3} T_{1 \mathrm{~g}} \rightarrow{ }^{1} A_{1 \mathrm{~g}}$ spinforbidden transition in $\mathrm{MoCl}_{6}{ }^{2-}$ ion is masked by an intense band of ${ }^{4} A_{2 \mathrm{~g}} \rightarrow{ }^{4} T_{2 \mathrm{~g}}$ transition in $\mathrm{MoCl}_{6}{ }^{3-}$ ion and could not be resolved with confidence.

Thus, depending on temperature, the reaction of $\mathrm{MoO}_{2}$ with $\mathrm{HCl}$ produced either Mo(IV) or a mixture of Mo(IV) and Mo(III) ions. The latter were formed as the result of disproportionation of Mo(IV) 

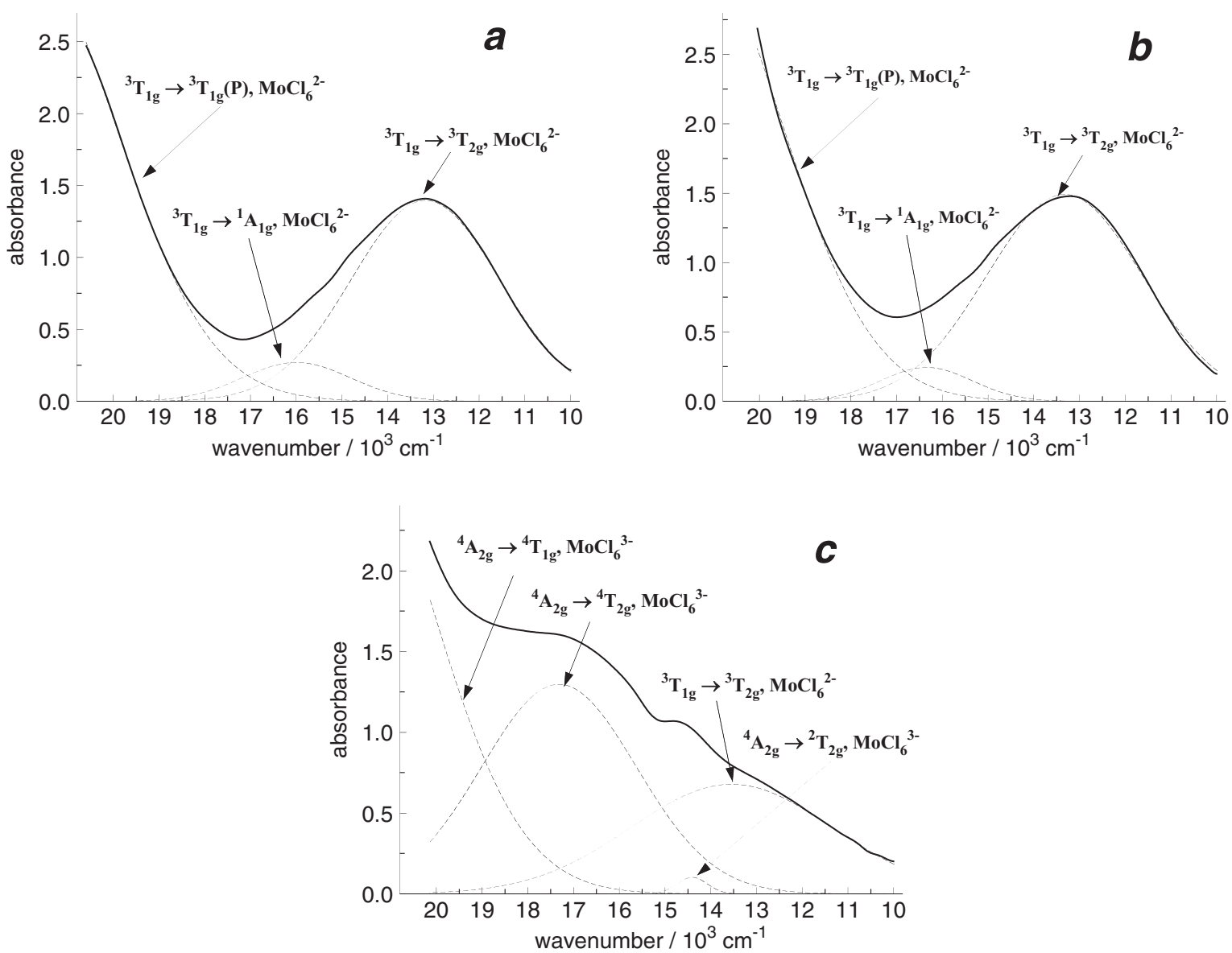

Figure 6. EAS of $\mathrm{NaCl}-\mathrm{KCl}-\mathrm{CsCl}$ eutectic based melts containing the products of reaction of $\mathrm{MoO}_{2}$ with $\mathrm{HCl}$. Experimental conditions: $823 \mathrm{~K}, 10$ min reaction time (a); $873 \mathrm{~K}, 11$ min reaction time (b); $923 \mathrm{~K}, 1$ min reaction time (c). Electronic transitions and ions are shown for each band.

species and the following reactions describe the process of $\mathrm{MoO}_{2}$ chlorination by $\mathrm{HCl}$ in a chloride melt:

$$
\begin{array}{r}
\mathrm{MoO}_{2}+2 \mathrm{HCl} \rightarrow \mathrm{MoOCl}_{2} \uparrow+\mathrm{H}_{2} \mathrm{O} \uparrow \\
\mathrm{MoO}_{2}+4 \mathrm{HCl}+2 \mathrm{Cl}^{-} \rightarrow \mathrm{MoCl}_{6}{ }^{2-}+2 \mathrm{H}_{2} \mathrm{O} \uparrow \\
2 \mathrm{MoCl}_{6}{ }^{2-} \rightarrow \mathrm{MoCl}_{6}{ }^{3-}+\mathrm{MoCl}_{6}{ }^{-} \\
\mathrm{MoCl}_{6}{ }^{-} \rightarrow \mathrm{MoCl}_{5} \uparrow+\mathrm{Cl}^{-}
\end{array}
$$

Molybdenum oxychloride $\left(\mathrm{MoOCl}_{2}\right)$ having a low boiling point sublimed (at least partially) from the melt and condensed in the form of yellow needles in the upper cold part of the experimental cell. Increasing temperature favored Reactions 13 and 14. The high vapor pressure of molybdenum( $(\mathrm{V})$ chloride assists its sublimation from the melt. A dark blue solid condensed in the upper part of the cell during the experiments at $650^{\circ} \mathrm{C}$ indicated the formation of $\mathrm{MoCl}_{5}$.

In a preliminary study, ${ }^{31}$ high temperature spectroscopy and spectroelectrochemistry measurements showed that $\mathrm{Mo}(\mathrm{III}) / \mathrm{Mo}(\mathrm{IV})$ oxidation/reduction was a reversible process, and $\mathrm{Mo}(\mathrm{III}) / \mathrm{Mo}(\mathrm{IV})$ redox potential was estimated from the results of spectroelectrochemistry in $\mathrm{NaCl}-\mathrm{CsCl}$ eutectic. At $823 \mathrm{~K}$ the potential found was $-(0.83 \pm 0.04)$ $\mathrm{V}$ vs. $\mathrm{Cl}^{-} / \mathrm{Cl}_{2}$ or $0.45 \pm 0.04 \mathrm{~V}$ vs. $\mathrm{Ag} / \mathrm{AgCl}$ reference electrode. In the present work, potentiometry measurements on an inert (glassy carbon) electrode were employed to determine $E^{*}{ }_{(\mathrm{Mo}(I I I) / \mathrm{Mo}(\mathrm{IV})}$ redox potentials. Chlorination of molybdenum metal by hydrogen chloride resulted in the melts containing only $\mathrm{Mo}(\mathrm{III})$ ions. Therefore, melts containing a mixture of $\mathrm{Mo}(\mathrm{III})$ and $\mathrm{Mo}(\mathrm{IV})$ ions were prepared by reacting a mixture of $\mathrm{Mo}$ and $\mathrm{MoO}_{2}$ with $\mathrm{HCl}$. The results obtained in $\mathrm{NaCl}-\mathrm{CsCl}$ and $\mathrm{NaCl}-\mathrm{KCl}-\mathrm{CsCl}$ based melts are summarized in Table IV. The primary factor affecting the value of $\mathrm{Mo}(\mathrm{III}) / \mathrm{Mo}(\mathrm{IV})$ redox potential is the ratio of $\mathrm{Mo}(\mathrm{IV})$ and $\mathrm{Mo}(\mathrm{III})$ concentrations in the melt, which in turn was calculated from the oxidimetrically determined mean oxidation state of molybdenum in the melt. Increased temperature resulted in a significant decreasing mean oxidation state with Mo(III) ions becoming predominant. The oxidimetric titration is, by its nature, not a very precise method as are all titrimetry techniques. Direct potentiometry measurements produced rather scattered data due to considerable uncertainty in determining mean oxidation state of molybdenum in the melt by redox titration (Table IV). Therefore the values of $E^{*}$ Mo(III)/Mo(IV) redox potentials given in Table IV should be considered as estimates. Analysis of the $E^{*}{ }_{\text {Mo(III)/Mo(IV) val- }}$ ues obtained, and comparison with the $E^{*}{ }_{\mathrm{Mo} / \mathrm{Mo}(\mathrm{III})}$ electrode potentials allowed, at the present stage, the derivation of the following equations of temperature dependencies of the formal standard redox potentials $\mathrm{Mo}(\mathrm{III}) / \mathrm{Mo}(\mathrm{IV})$ vs. $\mathrm{Cl}^{-} / \mathrm{Cl}_{2}$ couple:

$E^{*}{ }_{\mathrm{Mo}(\mathrm{IV}) / \mathrm{Mo}(\mathrm{III})}=-1.24+5.5110^{-4} \mathrm{~T}(\mathrm{NaCl}-\mathrm{CsCl}, 823-923 \mathrm{~K})$

$$
\begin{aligned}
& E^{*}{ }_{\mathrm{Mo}(\mathrm{IV}) / \mathrm{Mo}(\mathrm{III})} \\
& \quad=-0.97+3.0810^{-4} \mathrm{~T}(\mathrm{NaCl}-\mathrm{KCl}-\mathrm{CsCl}, 823-973 \mathrm{~K})
\end{aligned}
$$

Cyclic voltammetry was next employed to study molybdenum redox behavior. Gabriel et al. ${ }^{42}$ noted that cyclic voltammograms (CVs) 


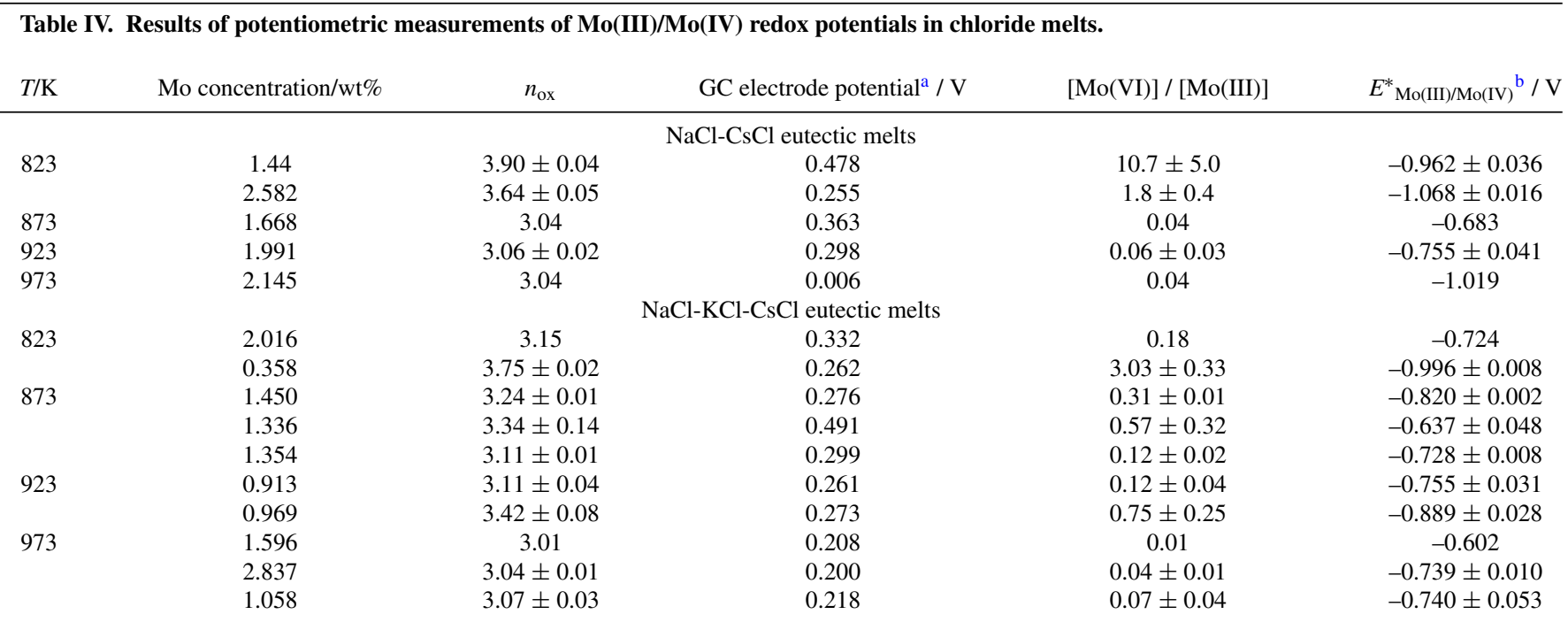

${ }^{\mathrm{a}}$ vs. $\mathrm{Ag} / \mathrm{AgCl}(1 \mathrm{~mol} . \%$ in $\mathrm{NaCl}-\mathrm{CsCl})$;

${ }^{\text {bs }} . \mathrm{Cl}^{-} / \mathrm{Cl}_{2}$.

recorded in $\mathrm{LiCl}-\mathrm{KCl}-\mathrm{K}_{3} \mathrm{MoCl}_{6}$ melts contained only one reduction peak attributed to a three-electron reduction of $\mathrm{Mo}$ (III) and a corresponding oxidation peak. Close examination of the $\mathrm{CV}$ presented by Gabriel et al. $^{42}$ however showed that there were one additional cathodic peak at the potential about $1.2 \mathrm{~V}$ more positive than Mo(III)to-Mo(0) reduction and one anodic peak, ca. $0.6 \mathrm{~V}$ more positive than $\mathrm{Mo}(0)$-to-Mo(III) oxidation. It was, therefore, of interest to investigate this process in more detail. In the present study the experiments were performed in $\mathrm{NaCl}-\mathrm{CsCl}$ and $\mathrm{NaCl}-\mathrm{KCl}-\mathrm{CsCl}$ based melts at 823 and 923 K. Examples of CVs recorded are presented in Fig. 7. The potential was scanned first in the anodic direction followed by a cathodic scan. The shape of the voltammograms is characteristic for a redox process involving soluble oxidized and reduced species. The anodic and cathodic waves have more positive potentials that the waves of $\mathrm{Mo}(\mathrm{III}) \leftrightarrow \mathrm{Mo}$ metal reduction/oxidation. The potentials also correspond to the values obtained in potentiometric measurements in $\mathrm{Mo}(\mathrm{III})+\mathrm{Mo}(\mathrm{IV})$ containing melts, Table IV .

Analysis of the cyclic voltammograms showed that the peak current is directly proportional to the square root of the scan rate and at low scan rates anodic and cathodic potentials are independent of the scan rate, Fig. 8. The anodic and cathodic processes are, therefore, controlled by diffusion of the electroactive species. The number of electrons $(n)$ was calculated from the difference of peak and half-peak potentials $\left(E_{\mathrm{P}}\right.$ and $\left.E_{\mathrm{P} / 2}\right)$ :

$$
E_{\mathrm{P}}-E_{\mathrm{P} / 2}=-2.2 \cdot R \cdot T /(n \cdot F)
$$

The value of $n$ obtained for the scan rates below $0.2 \mathrm{~V} / \mathrm{s}$ was $1.05 \pm$ 0.15 for the cathodic reaction and $1.10 \pm 0.15$ for the anodic reaction. The cyclic voltammograms recorded were therefore assigned to a one-electron $\mathrm{Mo}(\mathrm{III}) \leftrightarrow \mathrm{Mo}(\mathrm{IV})$ oxidation-reduction process. Formal standard redox potentials of the Mo(III)/(IV) couple were estimated from the results of cyclic voltammetry measurements using the halfpeak potential: ${ }^{44}$

$$
\mathrm{E}_{1 / 2}=\mathrm{E}_{\mathrm{Mo}(\mathrm{III}) / \mathrm{Mo}(\mathrm{IV})}^{0}+\frac{\mathrm{R} \cdot \mathrm{T}}{\mathrm{F}} \cdot \ln \left(\frac{\mathrm{D}_{\mathrm{Mo}(\mathrm{III})}}{\mathrm{D}_{\mathrm{Mo}(\mathrm{IV})}}\right)^{1 / 2}+\frac{\mathrm{R} \cdot \mathrm{T}}{\mathrm{F}} \cdot \ln \left(\frac{\gamma_{\mathrm{Mo}(\mathrm{III})}}{\gamma_{\mathrm{Mo}(\mathrm{IV})}}\right)
$$

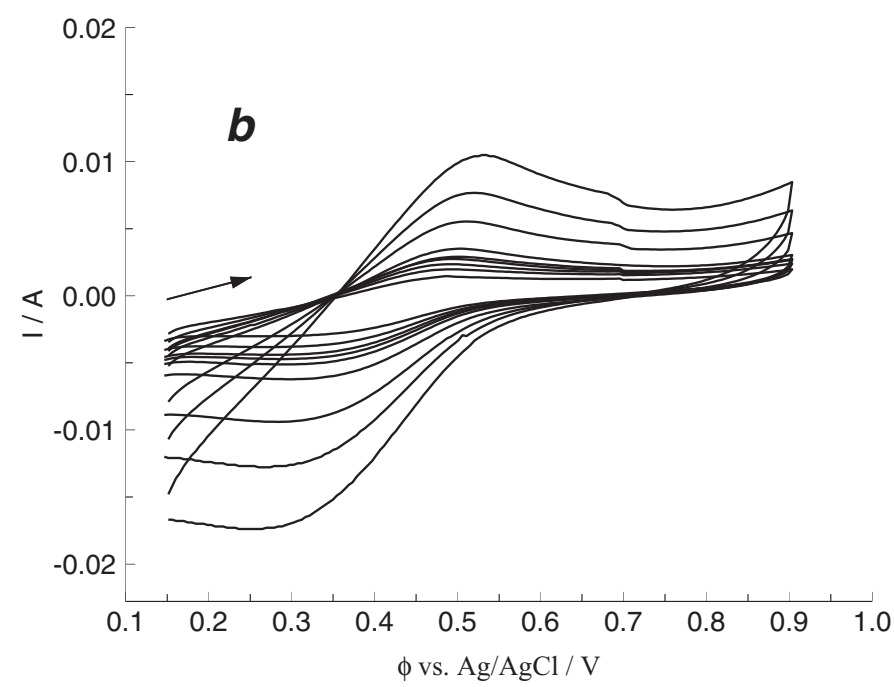

Figure 7. Cyclic voltammograms recorded in molybdenum containing melts. Glassy carbon working electrode, $0.048 \mathrm{~cm}^{2} ; \mathrm{Ag} / \mathrm{AgCl} \mathrm{reference;} \mathrm{Pb} / \mathrm{PbCl}{ }_{2}$ counter electrode. Scan rate, $\mathrm{V} \mathrm{s}^{-1}$ (inner to outer): 0.02; 0.04; 0.06; 0.08; 0.1; 0.2; 0.5; 1 and 2. Experimental conditions: (a) NaCl-KCl-CsCl, $923 \mathrm{~K}, 0.92 \mathrm{wt} \% \mathrm{Mo}$; (b) $\mathrm{NaCl}-\mathrm{CsCl}, 823 \mathrm{~K}, 1.07 \mathrm{wt} \% \mathrm{Mo}$. Arrows show the starting point and direction of the potential scan. 

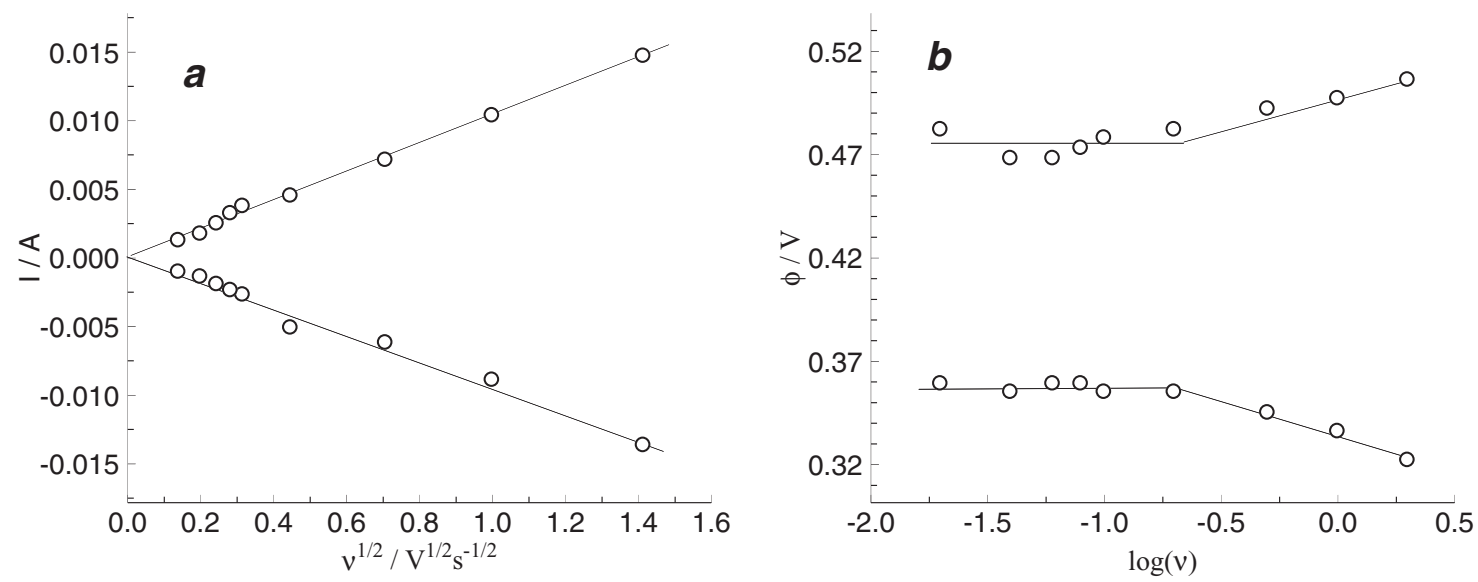

Figure 8. The effect of scan rate on anodic and cathodic currents in cyclic voltammograms (a) and anodic and cathodic peak potentials (b). Electrodes as in Fig. 7. Experimental conditions: (a) NaCl-KCl-CsCl, $923 \mathrm{~K}, 0.92 \mathrm{wt} \% \mathrm{Mo}$; (b) $\mathrm{NaCl}-\mathrm{CsCl}, 823 \mathrm{~K}, 1.07 \mathrm{wt} \% \mathrm{Mo}$.

Table V. Molybdenum(III)/(IV) formal standard redox potentials obtained from the results of cyclic voltammetry measurements, $\mathrm{Cl}^{-} / \mathrm{Cl}_{2}$ reference couple.

\begin{tabular}{cccc} 
Melt & $T / \mathrm{K}$ & $\begin{array}{c}\text { Mo concentration } \\
/ \text { wt } \%\end{array}$ & $\begin{array}{c}E^{*} \mathrm{Mo(III)/Mo(IV)} \\
/ \mathrm{V}\end{array}$ \\
\hline NaCl-CsCl & 823 & 0.17 & $-0.811 \pm 0.008$ \\
& & 0.27 & $-0.806 \pm 0.006$ \\
& & 0.68 & $-0.868 \pm 0.013$ \\
NaCl-KCl-CsCl & 833 & 1.07 & $-0.865 \pm 0.013$ \\
& & 0.85 & $-0.867 \pm 0.010$ \\
& 923 & 0.98 & $-0.873 \pm 0.006$ \\
& & 0.13 & $-0.902 \pm 0.008$ \\
& & 0.30 & $-0.950 \pm 0.020$ \\
& & 0.92 & $-1.096 \pm 0.025$
\end{tabular}

In dilute solutions the activity coefficients of dissolved species $(\gamma)$ remain essentially constant. Standard potential $E^{0}$ can therefore be changed to the formal standard potential $\mathrm{E}^{*}$ :

$$
\mathrm{E}_{\mathrm{Mo}(\mathrm{III}) / \mathrm{Mo}(\mathrm{IV})}^{*}=\mathrm{E}_{\mathrm{Mo}(\mathrm{III}) / \mathrm{Mo}(\mathrm{IV})}^{0}+\frac{\mathrm{R} \cdot \mathrm{T}}{\mathrm{F}} \cdot \ln \left(\frac{\gamma_{\mathrm{Mo}(\mathrm{III})}}{\gamma_{\mathrm{Mo}(\mathrm{IV})}}\right)
$$

To make an estimate of the formal standard redox potentials, the diffusion coefficients of the reduced and oxidized species are often taken as very close and the following equation is used: ${ }^{44}$

$$
\mathrm{E}_{\mathrm{Mo}(\mathrm{III}) / \mathrm{Mo}(\mathrm{IV})}^{*} \approx \mathrm{E}_{1 / 2}=\frac{\mathrm{E}_{\mathrm{P}}^{\mathrm{C}}+\mathrm{E}_{\mathrm{P}}^{\mathrm{A}}}{2}
$$

The results obtained are summarized in Table $\mathrm{V}$. The redox potential values are more positive than molybdenum electrode potentials, as expected. The $E^{*} \mathrm{Mo(III)/Mo(IV)}$ redox potentials estimated from the results of cyclic voltammetry are, however, more negative than those obtained by potentiometry ( $c f$. Tables IV and V). More accurate deter- mination of molybdenum redox potentials would require information on the diffusion coefficients of the molybdenum species.

Diffusion coefficients of molybdenum ions in alkali chloride melts.-Several transient electrochemical techniques can be utilized for determining molybdenum species diffusion coefficients in molten salts. Molybdenum containing melts based on the ternary $\mathrm{LiCl}-\mathrm{KCl}-$ $\mathrm{CsCl}$ eutectic were here studied using chronopotentiometry, and molybdenum ions diffusion coefficients were determined employing Sand's equation: ${ }^{42,45}$

$$
i \cdot \tau^{1 / 2}=1 / 2 \cdot n \cdot F \cdot A \cdot \pi^{1 / 2} \cdot C \cdot D^{1 / 2},
$$

where $i$ is the current, A; $\tau$ the transition time, $\mathrm{s} ; n$ the number of electrons; $F$ the Faraday constant, $\mathrm{C} / \mathrm{mol} ; A$ the plane electrode surface area, $\mathrm{cm}^{2} ; C$ the concentration of the reactant, $\mathrm{mol} / \mathrm{cm}^{3}$; and $D$ the diffusion coefficient of the reactant, $\mathrm{cm}^{2} / \mathrm{s}$. The results are presented in Table VI, where they are compared with the data available for LiCl$\mathrm{KCl}$ eutectic based melts. The agreement between the results is good; the diffusion coefficients increase with temperature and decreasing radius of alkali cation. In $\mathrm{LiCl}-\mathrm{KCl}-\mathrm{CsCl}$ melt the following equation describes the temperature dependence of $\mathrm{Mo}(\mathrm{III})$ ions diffusion coefficients:

$$
\log D_{\mathrm{Mo}(\mathrm{III})}=-3702.3 / T-0.9( \pm 0.3)
$$

For a flat working electrode the Randles-Sevcik equation can be employed to calculate the diffusion coefficients of the electroactive species: ${ }^{46}$

$$
i_{\mathrm{p}}=0.4463 \cdot n^{3 / 2} \cdot F^{3 / 2} \cdot A \cdot C \cdot \nu^{1 / 2} \cdot D^{1 / 2} /(R \cdot T)^{1 / 2},
$$

where $i_{p}$ is the peak current, $\mathrm{A} ; \nu$ the potential scan rate, $\mathrm{V} / \mathrm{s} ; R$ the universal gas constant, $\mathrm{J} /(\mathrm{mol} \cdot \mathrm{K}) ; T$ temperature, $\mathrm{K}$; and $n, F, A, C$ and $D$ are the same as in Eq. 21. Diffusion coefficients of Mo(III) ions in $\mathrm{NaCl}-\mathrm{CsCl}$ eutectic melts were determined from the analysis of the anodic waves of cyclic voltammograms and are included in Table VI. As expected, the diffusion coefficients increase with temperature or decreasing mean alkali cation radius. Analysis of the cathodic parts of

Table VI. Diffusion coefficients of molybdenium(III) chloro-ions in alkali chloride melts.

$\mathrm{LiCl}-\mathrm{KCl}$

\begin{tabular}{ccr}
\cline { 2 - 3 } $\mathrm{T}, \mathrm{K}$ & $D_{\text {Mo(III) }} \cdot 10^{5} / \mathrm{cm}^{2} / \mathrm{sec}$ & Sou \\
\hline 773 & $0.80 \pm 0.05$ & \\
823 & & \\
873 & 1.43 & \\
923 & & \\
1023 & &
\end{tabular}

LiCl-KCl-CsCl

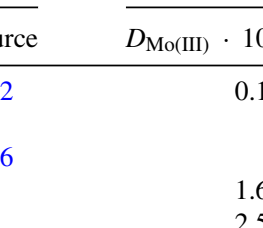

\begin{tabular}{cccc}
$10^{5} / \mathrm{cm}^{2} / \mathrm{sec}$ & Source & $D_{\mathrm{Mo}(\mathrm{III})} \cdot 10^{5} / \mathrm{cm}^{2} / \mathrm{sec}$ & Source \\
\hline .19 & present work & $0.37 \pm 0.14$ & present work
\end{tabular}

present work
present work 
the CVs allowed the estimation of Mo(IV) diffusion coefficients. In the $\mathrm{NaCl}-\mathrm{CsCl}$ melt at $823 \mathrm{~K}$ the diffusion coefficient thus obtained was $(0.58 \pm 0.28) \cdot 10^{-6} \mathrm{~cm}^{2} / \mathrm{sec}$, which is about 6 times less than the diffusion coefficient of Mo(III) ions.

\section{Conclusions}

The electrochemical behavior of molybdenum was studied in alkali chloride melts by stationary and transient electrochemical techniques and the speciation of molybdenum(III) and (IV) ions were characterized by electronic absorption spectroscopy. EAS measurements were also employed to assess the stability of Mo(III) ions in high temperature chloride melts. Increasing temperature or increasing ionic momentum of the melt cation decreases the stability of Mo(III) chloro-species and the rate of $\mathrm{Mo}$ (III) disproportionation reaction increases by an order of magnitude upon changing the melt from $\mathrm{CsCl}$ to $\mathrm{LiCl}$.

Formal standard electrode potentials of molybdenum were determined in a variety of alkali chloride based melts (individual chlorides and their mixtures) and compared with the data available in the literature. Increasing temperature or decreasing alkali cation radius

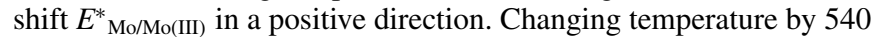
degrees results in a potential shift of about $300 \mathrm{mV}$ (for LiCl-KCl$\mathrm{CsCl}$ melt) and switching from $\mathrm{LiCl}$ to $\mathrm{CsCl}$ alters the potential by ca. $150 \mathrm{mV}$.

Molybdenum(III)/(IV) redox potentials were measured employing potentiometry and cyclic voltammetry and found to be $0.2-0.3 \mathrm{~V}$ more positive than $\mathrm{Mo} / \mathrm{Mo}$ (III) electrode potentials. The stability of $\mathrm{Mo}(\mathrm{IV})$ chloro-species decreases with temperature and at $923 \mathrm{~K}$ and above they undergo disproportionation into molybdenum(III) and (V) chlorides.

\section{References}

1. R. M. Hengstler, L. Beck, H. Breitkreutz, C. Jarousse, R. Jungwirth, W. Petry, W. Schmid, J. Schneider, and N. Wieschalla, J. Nucl. Mater, 402, 74 (2010).

2. V. P. Sinha, P. V. Hegde, G. J. Prasad, G. K. Dey, and H. S. Kamath, J. Alloys Comp., 491, 753 (2010).

3. A. Berche, N. Dupin, C. Guéneau, C. Rado, B. Sundman, and J. C. Dumas, J. Nucl. Mater, 411, 131 (2011).

4. V. P. Sinha, P. V. Hegde, G. J. Prasad, G. K. Dey, and H. S. Kamath, J. Alloys. Comp., 506, 253 (2010).

5. J. I. Bramman, R. M. Sharpe, D. Thom, and G. Yates, J. Nucl. Mater, 25, 201 (1968)

6. H. Kleykamp, J. Nucl. Mater., 131, 221 (1985).

7. S. Imoto, J. Nucl. Mater, 140, 19 (1986).

8. V. A. Volkovich, T. R. Griffiths, R. C. Thied, and B. Lewin, J. Nucl. Mater, 323, 93 (2003).

9. O. A. Ryzhik, State of Divalent and Trivalent Molybdenum in Molten Alkali Metal Chlorides, PhD thesis, Institute of Electrochemistry, Sverdlovsk (1965) (in Russian)

10. M. V. Smirnov, Electrode Potentials in Molten Chlorides, Nauka, Moscow (1973) (in Russian).
11. O. A. Ryzhik and M. V. Smirnov, Izv. Vys. Ucheb. Zav., Tsvet. Metallurgiya, (6), 103 (1963).

12. M. V. Smirnov and O. A. Ryzhik, Tr. Inst. Elektrokhim. UF AN SSSR, 6, 11 (1965).

13. M. V. Smirnov and O. A. Ryzhik, Tr. Inst. Elektrokhim. UF AN SSSR, 7, 27 (1965).

14. O. A. Ryzhik and M. V. Smirnov, Tr. Inst. Elektrokhim. UF AN SSSR, 7, 21 (1965)

15. O. A. Ryzhik and M. V. Smirnov, Tr. Inst. Elektrokhim. UF AN SSSR, 8, 43 (1966).

16. O. A. Ryzhik, Tr. Tambov. Inst. Khim. Mashinostr., (8), 66 (1972).

17. S. Senderoff and A. Brenner, J. Electrochem. Soc., 101, 31 (1954).

18. S. M. Selis, J. Electrochem. Soc., 113, 37 (1966).

19. A. N. Baraboshkin, Electrocrystallysation of Metals from Molten Salts, Nauka, Moscow, 1976 (in Russian)

20. E. P. Aleksandrov, B. D. Vasin, A. S. Kazakov, and S. P. Raspopin, Izv. Vys. Ucheb. Zav., Tsvet. Metallurgiya, (2), 59 (1979).

21. B. D. Vasin, V. A. Ivanov, I. V. Shulman, and S. P. Raspopin, Izv. Vys. Ucheb. Zav., Tsvet. Metallurgiya, (2), 68 (1987).

22. A. M. Martinez, Y. Castrillejo, B. Borresen, M. R. Bermejo, and M. Vega, J. Electroanal. Chem., 493, 1 (2000).

23. A. B. Ivanov, V. A. Volkovich, D. A. Poskryakov, B. D. Vasin, and T. R. Griffiths, AIP Conf. Proc., 1767, 020010 (2016).

24. A. B. Ivanov, V. A. Volkovich, M. A. Pukhov, K. O. Podlasova, D. A. Poskryakov, B. D. Vasin, and T. R. Griffiths, ECS Trans., 75(15), 417 (2016).

25. P. A. Arkhipov, A. N. Baraboshkin, Z. I. Veleev, and Z. C. Martem'yanova, Elektrokhimiya, 26, 1555 (1990).

26. S. Senderoff and G. W. Mellors, J. Electrochem. Soc., 114, 556 (1967).

27. D. Inman, R. S. Sethi, and R. Spencer, J. Electroanal. Chem., 29, 137 (1971).

28. D. Inman and R. Spencer, Adv. in Extractive Metallurgy and Refining, IMM paper 12 (1977).

29. V. A. Volkovich, D. A. Danilov, I. B. Polovov, B. D. Vasin, T. R. Griffiths, D. E. Aleksandrov, O. A. Tropin, and D. V. Tsarevskii, ECS Trans., 3(35), 555 (2007).

30. V. A. Volkovich, B. D. Vasin, O. A. Tropin, D. A. Danilov, and S. P. Raspopin, Russian Metallurgy (Metally), (2), 150 (2010).

31. V. A. Volkovich, I. B. Polovov, R. V. Kamalov, and T. R. Griffiths, ECS Trans., 33(7), 391 (2010).

32. S. Senderoff and A. Brenner, J. Electrochem. Soc., 101, 28 (1954).

33. T. Suzuki, Electrochim. Acta, 15, 127 (1970).

34. J. C. Gabriel, J. Bouteillon, J. C. Poignet, and J. M. Roman, J. Electrochem. Soc., 141, 2286 (1994).

35. A. B. Ivanov, V. A. Volkovich, P. Yu. Likhachev, and R. V. Kamalov, ECS Trans., 64(4), 377 (2014).

36. C. E. Crouthamel and C. E. Johnson, Anal. Chem., 26, 1284 (1954).

37. B. D. Vasin, S. V. Maslov, V. A. Volkovich, I. B. Polovov, S. A. Kazakov, and O. I. Rebrin, in Proc. 7-th Int. Symp. Molten Salts Chem. Techn., vol. 1, P. Taxil, C. Bessada, M. Cassir, and M. Gaune-Escard, Editors, p. 335, Toulouse (2005).

38. A. J. Bard and L. R. Faulkner, Electrochemical Methods: Fundamentals and Applications, John Wiley \& Sons, Inc., New York, pp. 48 (2001).

39. B. D. Vasin, S. P. Raspopin, and V. A. Ivanov, in VI Kola Symp. Electrochem. Rare and Non-ferrous Metals, Abstracts, p. 88, IKhTREMS, Apatity (1989) (in Russian).

40. T. B. Scheffler, C. L. Hussey, K. R. Seddon, C. M. Kear, and P. D. Armitage, Inorg. Chem., 22, 2099 (1983).

41. E. P. Aleksandrov, A. B. Alekseev, B. D. Vasin, and S. P. Raspopin, Izv. Vys. Ucheb. Zav., Tsvet. Metallurgiya, (1), 66 (1981).

42. J. C. Gabriel, D. Vincent, J. Bouteillon, J. C. Poignet, V. A. Volkovich, and T. R. Griffiths, Electrochim. Acta, 44, 4619 (1999).

43. R. D. Shannon, Acta Cryst. A, 32, 751 (1976).

44. S. A. Kuznetsov and M. Gaune-Escard, in Proc. 7-th Int. Symp. Molten Salts Chem. Techn., P. Taxil, C. Bessada, M. Cassir, and M. Gaune-Escard, Editors, vol. 2, p. 855, Toulouse (2005).

45. Ref. 39 , pp. 308 .

46. D. K. Gosser Jr., Cyclic Voltammetry: Simulation and Analysis of Reaction, VCH Publishers, Inc., New York, p. 42 (1993). 